\title{
Productivity and Profitability Enhancement in Little Millet through Frontline Demonstration in Vathalmalai Tribal Areas of Dharmapuri District of Tamil Nadu, India
}

\author{
M. A. Vennila ${ }^{1 *}$, R. Thangadurai ${ }^{1}$, M. Sangeetha ${ }^{1}$ and P. S. Shanmugam ${ }^{2}$ \\ ${ }^{1}$ ICAR ICAR-Krishi Vigyan Kendra, Dharmapuri, Tamil Nadu Agricultural University \\ Tamil Nadu, India \\ ${ }^{2}$ Department of Pulses, Agricultural College and Research Institute, Tamil Nadu Agricultural \\ University, Coimbatore - 641 003, Tamil Nadu, India \\ *Corresponding author
}

\begin{abstract}
A B S T R A C T
Frontline demonstration was taken up in the Vathalmalai tribal area of Dharmapuri district, Tamil Nadu, India during kharif 2016 to create awareness among the tribal farmers and demonstrate the improved production technologies in Little millet. The Improved Crop Management practices including cultivation of improved drought tolerant and short duration Little millet variety $\mathrm{CO} 4$, integrated management of nutrients, need based pest and disease management practices were demonstrated and compared with the existing farmers practice followed in Little millet cultivation. Results showed that demonstration of Little millet variety CO 4 with Improved Crop Management practices recorded higher grain yield of $1590 \mathrm{~kg} / \mathrm{ha}$ and farmers practice recorded lower yield of $1258 \mathrm{~kg} / \mathrm{ha}$. Adoption of Improved Crop Management practices increased the grain yield of Little millet to the tune of 23.74 per cent compared to farmers practice. Farmers earned higher net income of Rs.24410 /ha through the demonstration and Rs.17475/ha with farmers practice. Besides, farmers realized higher benefit cost ratio (2.59) through the demonstration compared to farmers practice (1.84). Thus, the frontline demonstration of improved variety with crop management practices increased the grain yield and net income of the farmers growing Little millet under rainfed condition. In this study, potential of the improved variety and technologies were demonstrated systematically and scientifically in the farmers field along with farmers practice for further adoption by farming community in large scale.
\end{abstract}

\section{Keywords}

Demonstration, Little millet, Grain yield, Net income Benefit cost ratio

\section{Article Info}

Accepted:

28 August 2020 Available Online: 10 September 2020

\section{Introduction}

Little millet, $P$. sumatrense, is native of India and is called Indian millet which is a major food crop for tribal people and the species name is based on a specimen collected from
Sumatra (Indonesia) (de Wet et al., 1983). It is mainly cultivated in the Caucasus, China, east Asia, India, and Malaysia. Little millet is adapted to both the climates of temperate and tropical. It can withstand both drought and water logging. At present the crop is almost 
confined to some hilly areas in India and is cultivated on about 500,000 ha. It is an important catch crop in some tribal farms in India (Kalaisekar et al., 2017). Little millet is one of the oldest crops cultivated in India and is important minor millet grown in dry lands. However, its utilization is restricted to only certain cultural occasions in certain parts of the country. Some of the millets are better than common cereals in protein, fat and mineral contents. There are several studies conducted on minor millets indicating utilization potential and variability including potential benefits in modern diets. Even though little millet is nutritionally superior to cereals, yet its utilization is limited. The major factor discouraging its cultivation and consumption is the drudgery associated with its processing (Mallikarjun et al., 2011). Little millet is the principal food grain of the rural population in India, especially in South India. It is very nutritious and rich in minerals, dietary fiber and essential amino acids. A member of sub-family Panicoideae of the family Poaceae, Samai (Panicum miliare L.) (Syn. Sumatrense Roth ex Roem. and Schult] is widely cultivated as a cereal across India, Nepal, Western Burma, Sri Lanka, Pakistan and South East Asian countries. It is grown both in the tropical and sub tropical regions and even at an altitude of 7000 feet (Daniel Sundararaj and Thulasidas, 1993). The crop is hardy and provides better yield even in degraded soils under adverse weather conditions. Presently samai is grown throughout India in more than half a million hectare with major area including Karnataka, Andhra Pradesh, Tamil Nadu, Orissa, Bihar, Maharashtra and Madhya Pradesh. The crop is often sown with the onset of monsoon season (Haider, 1997). Samai has high tolerance to heat and drought and highly suitable for extreme soil and climatic conditions. In Tamil Nadu, samai is grown in 20,000 ha during southwest (June-July) and northeast (September-October) monsoon with the productivity of $732 \mathrm{~kg} / \mathrm{ha}^{-1}$ in Dharmapuri, Krishinagiri, Salem, Namakkal, Erode, Coimbatore, Madurai and Vellore districts. A high yielding, drought resistant and short duration culture is the long felt need of the dry land, hill area and tribal farmers of Tamil Nadu.

Little millet is highly nutritious and good source of vitamin B, minerals like calcium, iron, zinc, potassium among other millets. It also provides essential amino acids and fat to the body, which helps to reduce weight. Its high fiber content is helps in making pongal or even kheer instead of rice (Reddy, 2017). It is mainly grown for its grains and it is highly nutritious. Its grains contain carbohydrate $(67 \%)$, protein $(7.7 \%)$, dietary fibre $(7.6 \%)$, minerals $(1.5 \%)$, iron $(9.3 \%)$ and calcium (17\%) (Kimeera Ambati and Sucharitha, 2019).

It is superior to rice and wheat, in respect of crude fibre, amino acids and minerals like calcium (344 mg/100g) and potassium (408 $\mathrm{mg} / 100 \mathrm{~g})$. It also contains anti nutrients such as phytates, polyphenols, tannins and trypsin inhibito Little millet and its products helps in managing diabetes and its complications by regulation of glucose homeostasis and prevention of dyslipideamia. It also gives protection against the risk of cardiovascular disease, gastrointestinal cancers and other health issues (Devi.et.al, 2014). Hence, there is a great demand for improving little millet production.

Little millet is one of the important millets grown extensively in Dharmapuri District. and it is being cultivated in an area of about 3977 hactares and out of which about 750 ha under vathalmalai tribal area. Little millet is mainly cultivated under rainfed condition during kharif season in Vathalmalai tribal area with little management in Vathalmalai Tribal areas of Morappur block. Now a days, 
the area under Little millet cultivation is shrinking especially under tribal areas because of lower yield and usage of old traditional and low yielding varieties used for cultivation. The productivity is very low when compared to state average and only 50 per cent of the state average is being realised in Morappur block due to lack of knowledge on high yielding drought tolerant varieties and non-adoption of improved cultivation practices, prevalence of nutrient deficiency, pest and disease incidence also lowers the Little millet productivity. In addition to that under rainfed condition, farmers facing the problem of moisture stress at various crop growth stages thereby experiencing low yield and crop loss to some extent.

Hence, the productivity of Little millet might be increased by growing suitable variety along with improved crop management practices. Similar studies on crop yield increase by adoption of improved crop management practices were reported by Subhashree et al., (2017) in Little millet; Sharma et al., (2016) and Singh (2017) in Wheat; Jat and Gupta (2015) in Pearl millet; Meena et al., (2014) in Maize. Considering the above facts, a frontline demonstration was proposed and conducted in the farmers' holdings to demonstrate the improved package of practices for higher productivity in Little millet under rainfed condition.

\section{Materials and Methods}

Frontline demonstration was conducted to demonstrate the potential of the drought tolerant, short duration variety with the improved package of practices in comparison with the existing farmers practice in the Vathalmalai tribal farmers' holdings of Dharmapuri district during kharif 2016 under rainfed condition. Vathalmalai hill is geographically perched at a height of 1090 metres $(3600 \mathrm{ft})$ above mean sea level with predominantly tribal population engaged in the cultivation of ragi, sorghum, samai, avarai and silver oak. Higher prevalence of illiteracy, remoteness of the location, adoption of conventional practices in agriculture and meagre exposure to technological progress were the main constraints in enhancing the productivity of millets.

Demonstration was conducted in 20 locations spread over in 7 villages viz., Palsilambu, Periyur, Chinnangadu, Kotlangadu, Mannanguli, Ondriyangadu and Naickanur tribal villages of Dharmapuri District under the project funded by State Planning Commission under State Balanced Growth Fund (SBGF). The soils of the demonstration fields were collected and analysed for its initial soil nutrients status. The results showed that the soils were slightly alkaline in soil reaction, non saline, low in nitrogen, medium in phosphorus and potassium nutrient content.

Each demonstration was conducted in an area of 0.4 ha and with an adjacent area of 0.4 ha selected for farmers practice. The integrated crop management practices including cultivation of Little millet variety $\mathrm{CO} 4$, integrated nutrient management, integrated pest and disease management practices were demonstrated in the demonstration along with the farmers practice. Little millet variety $\mathrm{CO}$ 4 was released from Tamil Nadu Agricultural University, Coimbatore during 2008. Being a short duration variety has 75- 80 days duration, it fits well in the existing double cropped rainfed situation of North, North Western and Western zones of Tamil Nadu where little millet is grown during June-July as a preceding crop to pulse crop. It is a high yielding variety, no pest and disease incidence in normal season and palatable fodder. (Nirmalakumari et al., 2006) Little millet local variety was grown with the existing farmers practices such as broadcasting of seeds and basal application of FYM, etc. The 
details on the technological interventions followed in the demonstration and farmers practice were given in Table 1. Before initiating the demonstration, the beneficiary farmers were trained in all the improved practices in Little millet cultivation and followed in the demonstrations. Demonstration field were periodically observed by the scientists of Krishi Vigyan Kendra, Dharmapuri and advisory recommendations given in Crop Production Guide 2012, Tamil Nadu Agricultural University were followed. At the time of harvest, the data on plant population (number), plant height $(\mathrm{cm})$, number of tillers per plant (number), days taken for $50 \%$ flowering (number) and grain yield ( $\mathrm{kg} / \mathrm{ha}$ ) of Little millet crop were recorded from both the demonstration and farmers practice. Based on the cost of inputs and market price of the produce, economic parameters such as net return (Rs/ha) and benefit cost ratio were worked out.

\section{Results and Discussion}

Results of the study revealed that demonstration of drought tolerant Little millet variety $\mathrm{CO} 4$ with Improved Crop Management practices recorded the higher plant population $\left(46.4 / \mathrm{m}^{2}\right)$, plant height $(118.6 \mathrm{~cm})$ and higher number of tillers per plant (5.62). Lower plant population $(35.2 / \mathrm{m} 2)$, plant height $(95.4 \mathrm{~cm})$ and number of tillers per plant (4.28) were recorded in farmers practice during 2016 (Table 2). The demonstrated variety attained maturity one week earlier than the existing local variety. Cultivation of drought tolerant Little millet variety $\mathrm{CO} 4$ with Improved Crop Management practices recorded higher average grain yield of $2140 \mathrm{~kg} / \mathrm{ha}$ (Table 3). Farmers practice recorded lower average grain yield of $1590 \mathrm{~kg} / \mathrm{ha}$. Adoption of improved practices increased the yield of Little millet to the tune of 23.74 per cent compared to the farmers practice under rainfed condition.

Table.1 Technological interventions followed in Little millet cultivation under demonstration and farmers practice in Dharmapuri district during 2016

\begin{tabular}{|c|c|c|c|}
\hline Sl.No. & $\begin{array}{l}\text { Technological } \\
\text { Intervention }\end{array}$ & Farmers Practice & $\begin{array}{l}\text { Improved production practices demonstrated through } \\
\text { frontline demonstration }\end{array}$ \\
\hline 1. & Farming situation & Rainfed & Rainfed \\
\hline 2. & Variety & $\begin{array}{l}\text { Cultivation of local } \\
\text { traditional variety }\end{array}$ & Cultivation of CO 4 samai variety \\
\hline 3. & Time of sowing & First week of June & First week of July \\
\hline 4. & Method of sowing & $\begin{array}{l}\text { Broadcasting of seeds and } \\
\text { thinning operation was not } \\
\text { done }\end{array}$ & $\begin{array}{l}\text { Broadcasting of seeds and spacing of } 30 \mathrm{X} 10 \mathrm{~cm} \text { followed by } \\
\text { thinning and gap filling operation }\end{array}$ \\
\hline 5. & $\begin{array}{l}\text { Seed } \\
\text { practice }\end{array}$ & Not followed & $\begin{array}{l}\text { Seed treatment with Pseudomonas fluorescens @ } 10 \mathrm{gm} / \mathrm{kg} \text { of } \\
\text { seed followed by biofertilizers viz., Azospirillum and } \\
\text { Phosphobacteria each @ } 25 \mathrm{gm} / \mathrm{kg}\end{array}$ \\
\hline 6. & $\begin{array}{l}\text { Nutrient } \\
\text { Management }\end{array}$ & $\begin{array}{l}\text { Basal application of FYM @ } \\
1 \text { t/ha }\end{array}$ & $\begin{array}{l}\text { Basal application of FYM @ } 12.5 \mathrm{t} / \mathrm{ha} \text {; Recommended dose of } \\
\text { NPK @ } 40: 20: 20 \mathrm{~kg} / \mathrm{ha} \text {; Soil application of TNAU millet } \\
\text { micronutrient mixture @ } 5 \mathrm{~kg} / \mathrm{ha}\end{array}$ \\
\hline 7. & Weed management & Not followed & One hand weeding on 25- 30 days after sowing \\
\hline 8. & IPDM Practices & $\begin{array}{l}\text { No prophylactic or control } \\
\text { measures for managing pests } \\
\text { and diseases }\end{array}$ & $\begin{array}{l}\text { Need based usage of plant protection chemicals and IDM } \\
\text { practices }\end{array}$ \\
\hline
\end{tabular}


Table.2 Growth parameters of Little millet varieties local variety and $\mathrm{CO} 4$ as influenced by farming practices

\begin{tabular}{|c|l|c|c|}
\hline Sl. No. & \multicolumn{1}{|c|}{ Parameters } & $\begin{array}{c}\text { Farmers Practice } \\
\text { Local variety }\end{array}$ & $\begin{array}{c}\text { Demonstration of } \\
\text { improved practices } \\
\text { with Co4 variety }\end{array}$ \\
\hline 1. & Plant population at harvest (No./m2) & 35.2 & 46.4 \\
\hline 2. & Plant height (cm) & 95.4 & 118.6 \\
\hline 3. & Number of productive tillers per plant & 13.28 & 15.62 \\
\hline 4. & Days to 50\% flowering & 48 & 62 \\
\hline 5. & Grain yield / plant (gms) & 8 & 15 \\
\hline
\end{tabular}

Table.3 Yield and economics of Little millet varieties local and CO 4 with Improved farming practices

\begin{tabular}{|l|c|c|c|c|c|}
\hline \multicolumn{1}{|c|}{ Treatments } & $\begin{array}{c}\text { Grain } \\
\text { yield (Kg/ } \\
\text { ha) }\end{array}$ & $\begin{array}{c}\text { Per cent yield } \\
\text { increase over } \\
\text { farmers } \\
\text { practice }\end{array}$ & $\begin{array}{c}\text { Gross cost } \\
\text { (Rs./ ha) }\end{array}$ & $\begin{array}{c}\text { Net Income } \\
\text { (Rs./ ha) }\end{array}$ & $\begin{array}{c}\text { Benefit } \\
\text { Cost } \\
\text { Ratio }\end{array}$ \\
\hline $\begin{array}{l}\text { Farmers practice (Local } \\
\text { variety) }\end{array}$ & 1285 & - & 14650 & 17475 & 1.84 \\
\hline $\begin{array}{l}\text { Demonstration of improved } \\
\text { practices (CO 4) }\end{array}$ & 1590 & 23.74 & 15340 & 24410 & 2.59 \\
\hline
\end{tabular}

The increased yield under demonstration might be due to the combined effect of high yielding, drought tolerant variety and adoption of improved crop management practices. The similar results of yield enhancement through front line demonstration of improved technologies has been reported by Kumar et al., (2010) in bajra; Solanki et al., (2014) in maize and Anand Naik et al., (2016) in sorghum. Besides, the incidence of shoot fly was not reported in the demonstrated variety and it was 8 per cent in the farmers practice.

The data on economic indicators indicated that, the cost of production was higher in demonstration (Rs. 15,340/ha) and lower in farmers practice (Rs.14,650/ha) (Table 3). Farmers earned the net income of about Rs.24,410/ha through the cultivation of CO 4 variety with Improved Crop Management practices and Rs.17,475/ha with farmers practice. On an average Rs. 6935/ha as additional income is attributed to the higher yield obtained in demonstration. Hence, farmers realized the higher benefit cost ratio (2.59) through the cultivation of $\mathrm{CO} 4$ variety with Improved Crop Management practices compared to farmers practice (1.84). It might be due to the higher grain yield recorded in demonstration compared to farmers practice. Similar results of increase in net income and benefit cost ratio due to adoption of improved technologies in the demonstrations were reported by Jat and Gupta (2015) in pearl millet; Dhaka et al., (2010) in maize and Anand Naik et al., (2016) in sorghum.

In conclusion the results of the demonstration revealed that cultivation of Little millet variety $\mathrm{CO} 4$ with Improved Crop Management practices increased the yield and income of the farmers under rainfed condition. In addition, the introduced variety 
has satisfied the farmers preferences such as high tiller production, early maturity and tolerance to grain shattering or dusting. Hence, the farmers were convinced with the performance of the variety with regard to its yield potential and tolerance to biotic and abiotic stresses under rainfed condition.

\section{References}

Anand Naik, Raju, G., Teggelli, Zaheer Ahamed, B. and Devappagouda $\mathrm{H}$. Patil. (2016). Yield gap analysis of sorghum through front line demonstrations in Kalaburagi region of northern Karnataka. Res. Envi-ron. Life Sci., 9(5): 597-598.

Daniel Sundararaj, D. and Thulasidas, G. (1993). The little millet (Panicum miliare Linn.) In: Botany of field crops Eds. D. Daniel Sundararaj and G.Thulasidas published by Macmillan India Limited, New Delhi P.108.

Devi, P.B., Vijayabharathi, R., Sathyabama, S., Mal-leshi, N.G. and Priyadarisini, V.B. (2014). Health benefits of Little millet (Eleusine coracana L.) polyphenols and dietary fibre: a review. J. Food Sci. Tech-nol., 51(6): 10211040. DOI: $10.1007 / \mathrm{s} 13197-011-0584-9$

Dhaka, B.L., Meena, B.S. and Suwalka, R.L. (2010). Popularization of improved maize production technology through frontline demonstrations in southeastern Rajasthan. Journal of Agricultural Science, 1(1): 39-42. DOI: 10.1080/09766898.2010.11884652

Haider, Z.A. (1997). Little millet in Indian Agriculture: Progress and perspectives. In : Extended summaries of National Seminar on Small millets organized by Indian Council of Agricultural Research and Tamil Nadu Agricultural University held at Tamil Nadu Agricultural University, Coimbatore during 23-24, April 1997. P. 5-6.
Jat, B. L. and Gupta, J. K. (2015). Yield gap analysis of pearl millet through frontline demonstrations in Dausa district of Rajasthan. Karnataka. J. Agric. Sci., 28(1): 104-106.

Kalaisekar, A., Padmaja. P.V., Bhagwat, V.R. and Patil, J.V. 2017. Introduction Little Millet, Panicum sumatrense In: Insect Pests of Millets published by Academic Press, London, USA, P.190.

Kimeera Ambati and Sucharitha K V 2019.Millets -Review on Nutritional Profiles and Health Benefits, International Journal of Recent Scientific Research 10(7), pp. 3394333948 .

Kumar, A., Kumar, R., Yadav, V.P.S. and Kumar, R.A. (2010). Impact assessment of frontline demonstrations of bajra in Haryana state. Indian Res. J. Ext. Edu., 10 (1): 105-108.

Mallikarjun Y Kamatar, Hemalatha S, Meghana DR, Sharanappa Talawar and Rama K. Naik. 2013. Evaluation of Little Millet (Panicum sumatrense) Land Races for Cooking and Nutritional Composition. Current Research in Biological and Pharmaceutical Sciences, 2(1): 7-11.

Meena, B. L., Meena, R. P., Meena, R. R., \& Singh, B. (2014). Popularization of improved maize (Zea mays L.) production technology through frontline demonstrations in semi arid zone IVA of Rajasthan. Journal of Applied and Natural Science, 6(2), 763-769. https://doi.org/10.31018/jans.v6i2.533

Reddy, O.S.K. (2017), Smart Millet and Human Health, Green Universe Environmental Services Society.

Sharma,V., Vijay Kumar, Sharma, S.C. and Sukhvinder Singh. (2016). Productivity enhancement and popularization of improved production technologies in wheat through frontline demonstrations. Journal of Applied and Natural Science, 
$8 \quad$ (1): $\quad 423-428 . \quad$ DOI: 10.31018/jans.v8i1.810

Singh, S.B. (2017). Impact of frontline demonstrations on yield of wheat (Triticum aestivum) under rain fed condition in Uttarakhand. International Journal of Science, Environment and Technology, 6(1): $779-786$.

Solanki, R.L., Rathore, R.S., Dhakar, S.D. and Kanojia, Y. (2014). Yield gap analysis of integrated nu-trient management in maize through front line demonstration. International Journal of Plant Sciences, 9(2): 438-440.

Subhashree, K.S., Ravishankar, C.R., Raveendra, H.R., Madhusudhan, K. (2017). Economic impact of front line demonstrations on Little millet yields. Agri-culture Update, 12(1): 169-171. DOI : $10.15740 / \mathrm{HAS} / \mathrm{AU} / 12.1 / 169-171$.

\section{How to cite this article:}

Vennila, M. A., R. Thangadurai, M. Sangeetha and Shanmugam, P. S. 2020. Productivity and Profitability Enhancement in Little Millet through Frontline Demonstration in Vathalmalai Tribal Areas of Dharmapuri District of Tamil Nadu. Int.J.Curr.Microbiol.App.Sci. 9(09): 36193625. doi: https://doi.org/10.20546/ijcmas.2020.909.447 